\title{
Deviations in populations of peripheral blood mononuclear cells and endometrial macrophages in the cow during pregnancy
}

\author{
Lilian J Oliveira and P J Hansen \\ Department of Animal Sciences, University of Florida, PO Box 110910, Gainesville, Florida 32611-0910, USA \\ Correspondence should be addressed to P J Hansen; Email: hansen@animal.ufl.edu
}

\begin{abstract}
The presence of conceptus alloantigens necessitates changes in maternal immune function. Here, we used the cow to evaluate whether species with epitheliochorial placentation have changes in specific leukocyte populations during pregnancy similar to those reported in species with hemotropic placentae. At days 33-34 of pregnancy, there was no effect of pregnancy status on the number of cells positive for CD8, CD4, $\gamma \delta \mathrm{T}$ cell receptor, or the monocyte marker CD68 in the peripheral blood mononuclear cell (PBMC) population. There was, however, an increase in the proportion of $\mathrm{CD4}^{+}$cells that were positive for $\mathrm{CD25}$. There was no effect of status on the proportion of PBMCs that were $\mathrm{CD8}^{+}$when comparing preparturient cows to nonpregnant cows. However, preparturient cows had an increased percentage of PBMCs that were $\gamma \delta \mathrm{T}$ cells and $\mathrm{CD}^{+}{ }^{+} \mathrm{CD} 25^{+}$and a tendency for a lower percentage that were $\mathrm{CD} 68^{+}$cells. Using immunolocalization with anti-CD68, it was found that pregnant cows had increased numbers of $\mathrm{CD68}^{+}$cells in the endometrial stroma as early as days 54-100 of gestation; this increase persisted through the last time examined (day 240 of gestation). Cells positive for CD68 were also positive for another macrophage/monocyte marker, CD14. In conclusion, pregnancy in the cow is associated with changes in peripheral and endometrial leukocyte numbers, which are similar to patterns observed in other species.
\end{abstract}

Reproduction (2008) 136 481-490

\section{Introduction}

Pregnancy is an immunologically distinct period for the eutherian female because the presence of conceptus alloantigens necessitates changes in maternal immune function to prevent immunological destruction of the conceptus. These changes can be observed systemically and at the fetal-maternal interface. Maternal immune adjustments to pregnancy have been most clearly defined in the human and mouse. Both of these species have an invasive, hemotropic placenta in which trophoblast invades the endometrium. Among the changes in immune function during pregnancy are an increase in circulating regulatory $\mathrm{T}$ cells $\left(\mathrm{T}_{\text {reg }}\right)$, defined as $\mathrm{CD} 4{ }^{+} \mathrm{CD} 25^{+} \mathrm{FOXP}^{+}$cells, that function to downregulate T lymphocyte function (Aluvihare et al. 2004, Somerset et al. 2004, Yang et al. 2008); a temporary anergy of maternal lymphocytes to conceptus MHC class I antigens (Tafuri et al. 1995); and synthesis of immunosuppressive proteins at the maternal-fetal interface including interleukin 10 (IL10; Hanna et al. 2000, Murphy et al. 2005) and transforming growth factor $\beta 1$ (TGFB1; Suzuki et al. 1995, Gorivodsky et al. 1999, Simpson et al. 2002). In addition, pregnancy is characterized by an increase in the number of specific leukocyte populations within the uterus including macrophages (Hunt et al. 1985, Heikkinen et al. 2003, Cupurdija et al.
2004, Kim et al. 2007), $\gamma \delta T$ cells (Heyborne et al. 1992, Mincheva-Nilsson et al. 1992, 1997), and natural killer (NK) cells (Bilinski et al. 2008, Shigeru et al. 2008). These cells have been implicated in vascular remodeling (NK cells: Bilinski et al. 2008); immunosuppression through secretion of IL10 and TGFB1 $(\gamma \delta$ T cells: Suzuki et al. 1995, Nagaeva et al. 2002; NK cells: Murphy et al. 2005) and parturition (macrophages: Thomson et al. 1999, Mackler et al. 2000).

One of the characteristics of pregnancy in eutherian mammals is great diversity in placental anatomy and uterine function. At three separate times in mammalian evolution, epitheliochorial placentation arose as a specialization from an ancestral hemotropic placenta: in lemurs, moles, and in the ancestor of cetartiodactyls, suidae, and perrisodactyls (Vogel 2005). Evolutionary pressure for development of this type of placentation could have involved increased efficiency of placental transport (Leiser et al. 1997) and increased maternal control over the vascular supply to the conceptus (Mess \& Carter 2007). The epitheliochorial placenta might also have evolved as a strategy for immunological defense of the conceptus. The apposition of placental trophoblast and endometrial epithelium in species with epitheliochorial placentation has been compared with the immunological relationship between commensal bacteria and host organisms, with little immunological 
recognition occurring unless the epithelial barrier is breached (Moffett \& Loke 2006). There is some evidence, however, that the immunological adjustments to pregnancy in species with epitheliochorial placentation are similar to those seen in the mouse and human. In the sheep, for example, pregnancy is associated with an increase in the number of macrophages in stroma (Tekin \& Hansen 2004) and in the number of $\gamma \delta$ T cells in the luminal epithelium and immediately adjacent stroma (Lee et al. 1992, Majewski et al. 2001). There is evidence for specific downregulation of maternal cytotoxic lymphocytes towards paternal antigens in pregnant mares (Baker et al. 1999), and there is accumulation of cells with NK activity during early pregnancy in the pig (Yu et al. 1993).

For the present series of experiments, the cow was used as a model to define the changes in immune function during pregnancy with a view to test whether the changes in immune function seen in human and mice are also seen in a species with epitheliochorial placentation. The specific hypotheses tested were that $\mathrm{CD} 4{ }^{+} \mathrm{CD} 25^{+}$cells increase in circulation during pregnancy, while circulating concentrations of $\gamma \delta \mathrm{T}$ cells and macrophages decrease. Moreover, it was hypothesized that the reduction in the number of the latter two cell types reflects recruitment to the uterus. Identification of these or similar changes in immune function during pregnancy would strengthen the notion that existence of an epitheliochorial placenta does not minimize the need for immunological adjustments in pregnancy. Moreover, such changes could result in an altered immune function in the preparturient period when the female is susceptible to uterine infection and other immune challenges.

\section{Results}

\section{Representative flow cytometry patterns}

Typical dot plots are shown in Fig. 1. Analysis of peripheral blood mononuclear cells (PBMCs) by side and forward scatter resolved cells into two populations (Fig. 1A). The first, more abundant population was of small size and little granularity, and represents lymphocytes primarily. The second population, which represents monocytes primarily, was of large size and granularity. Expression of markers for T cells (CD4, CD8, and CD25) was based on the cells in the lymphocyte gate. Expression of $\gamma \delta \mathrm{T}$ and CD68 was analyzed in both lymphocyte and monocyte regions. Cells positive for antibody could be readily distinguished from negative cells based on increased fluorescence when compared with cells stained with IgG (Fig. 1B-G). Cells positive for CD25 were resolved into two populations - a CD25 bright and a CD25 dim population (Fig. 1C). There were, however, no treatment differences in the percentage of $\mathrm{CD} 25^{+}$cells that were bright and $\operatorname{dim}$. Therefore, data were analyzed after pooling both populations.

\section{Differences between pregnant and nonpregnant cows at days 33-34 of gestation in subpopulations of PBMCs}

There were no differences between pregnant and nonpregnant cows in the proportions of PBMCs that were positive for CD4 and CD8 (Fig. 2A). Pregnant cows had, however, a higher $(P<0.06)$ percentage of PBMCs that were $\mathrm{CD} 25^{+}$(Fig. 2A). Moreover, the percentage of $\mathrm{CD}^{+}{ }^{+}$cells that were also positive for $\mathrm{CD} 25$ was higher $(P<0.05)$ for pregnant cows (Fig. 2C).

There was no effect of pregnancy status on the proportion of PBMCs in the lymphocyte and monocyte gates that were $\gamma \delta \mathrm{T}^{+}$and $\mathrm{CD}^{+} 8^{+}$cells (Fig. 2D and E).

\section{Differences between preparturient and nonpregnant cows in subpopulations of PBMCs}

There was no effect of pregnancy status on the percentage of cells in the lymphocyte gate that were positive for CD8 (Fig. 3A). However, the percentage of cells in the lymphocyte gate that were $\mathrm{CD} 4{ }^{+}, \mathrm{CD}_{2} 5^{+}$, and $\mathrm{CD} 4{ }^{+} \mathrm{CD} 25^{+}$were higher $(P<0.05)$ for preparturient cows than for nonpregnant cows (Fig. $3 \mathrm{~A}$ and $\mathrm{B}$ ). The increase in the number of $\mathrm{CD} 4{ }^{+} \mathrm{CD} 25^{+}$cells represents an increase in $\mathrm{CD}_{4}^{+}$cells and an increase in the proportion of $\mathrm{CD} 4{ }^{+}$cells that were $\mathrm{CD} 25^{+}$because the number of $\mathrm{CD}^{+}$that were $\mathrm{CD} 25^{+}$cells was higher $(P<0.05)$ in preparturient cows (Fig. 3C). Preparturient cows also had a greater proportion of cells in the lymphocyte gate that were $\gamma \delta T^{+}(P<0.01)$ and a tendency for a greater proportion of cells in the monocyte gate that were $\gamma \delta$ T cells $(P<0.07 ;$ Fig. 3D). There was also a tendency $(P<0.10)$ for the percentage of cells that were $\mathrm{CD}_{68}{ }^{+}$to be lower for preparturient cows for the monocyte gate (Fig. 3E).

\section{Immunolocalization of $\mathrm{CDE8}^{+}$and $\mathrm{CD}^{+} 4^{+}$cells in endometrium as affected by pregnancy status}

Cells positive for CD68 were very abundant in the lamina propria of the endometrial stroma in pregnant cows (Fig. 4B and C). A fewer number of positive cells were present in the submucosa. There were no $\mathrm{CD} 8^{+}$ cells in the luminal or glandular epithelia. In contrast to the pattern in pregnancy, there were very few $\mathrm{CD}_{6}{ }^{+}$ cells in the endometrium from nonpregnant cows (Fig. 4A). The pattern of $\mathrm{CD} 14^{+}$cells was very similar to that for CD68 (Fig. 4D).

The high degree of staining for CD68 in pregnant endometrium made counting of individual cells impossible. Instead, a subjective score for staining intensity was used to determine the pregnancy status effects on the number of $\mathrm{CD}^{+} 8^{+}$cells. Staining intensity was greater for pregnant cows than for nonpregnant cows at all stages of pregnancy examined $(P<0.05)$ for both the lamina propria (Fig. 5A) and submucosa (Fig. 5B). 

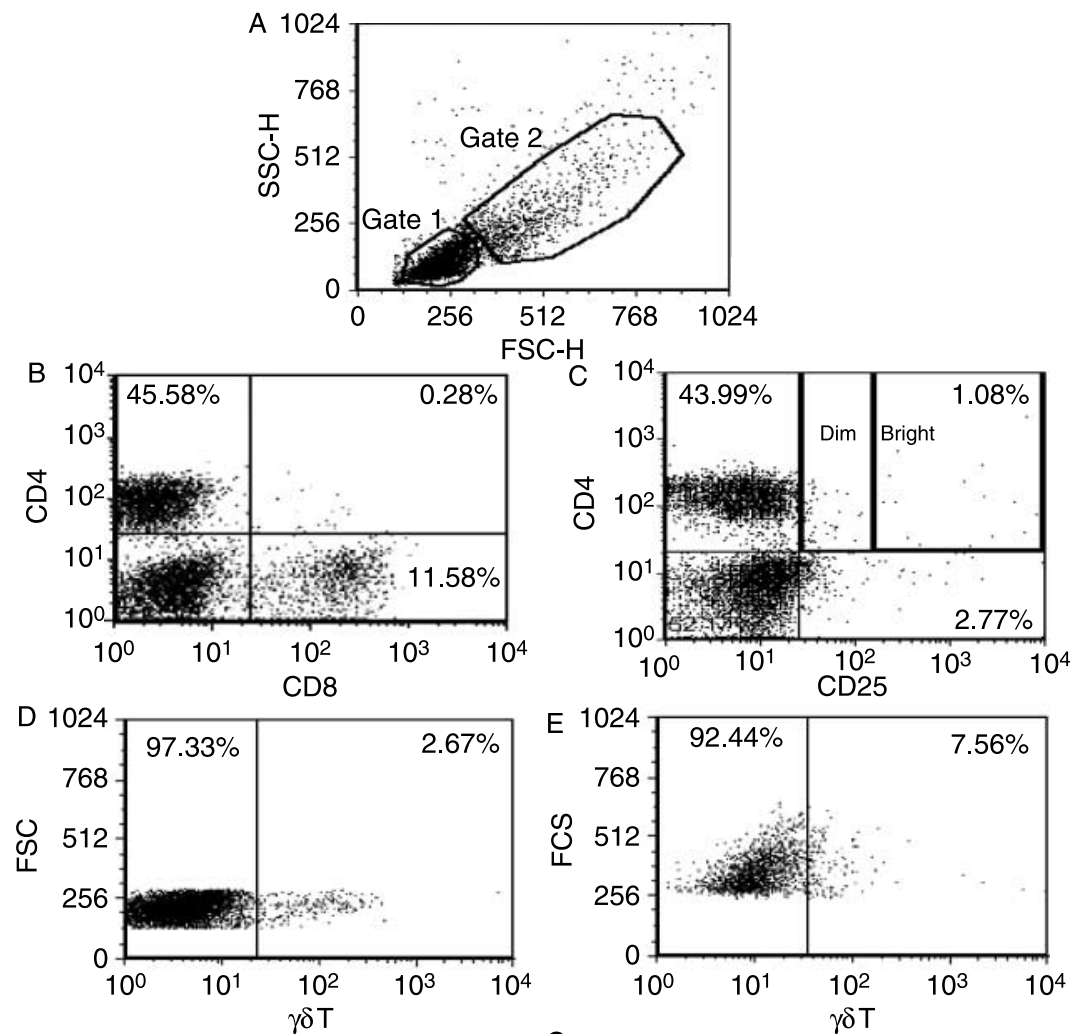

Figure 1 Representative acquisition dot plots to analyze subpopulations of bovine peripheral blood mononuclear cells. (A) Forward ( $x$-axis) and side (y-axis) scatter plots to analyze cells on the basis of size ( $x$-axis) and granularity ( $y$-axis). The lymphocyte (gate 1) and monocyte (gate 2) gates are circled. (B) Dual labeling for CD4 ( $y$-axis) and CD8 ( $x$-axis) among the cells in the lymphocyte gate. (C) Dual labeling of CD4 ( $y$-axis) and CD25 ( $x$-axis) for the cells in the lymphocyte gate. Note that CD25 labeling could be categorized as dim or bright. (D-G) Labeling of $\gamma \delta \mathrm{T}$ cells (D and E) and CD68 ( $F$ and $G$ ) in the lymphocyte gate $(\mathrm{D}$ and $\mathrm{F})$ and monocyte gate (E and $\mathrm{G})$. For D-G, the $x$-axis represents fluorescence and the $y$-axis represents forward scatter (FSC).

The co-localization of CD68 and CD14 expression was analyzed by dual-color immunofluorescence. In one experiment, two-color immunofluorescent labeling of endometrial sections was performed using antibodies to CD68 and CD14. The majority of $\mathrm{CD} 14^{+}$cells were positive for CD68 (Fig. 6). In the second experiment, two-color immunofluorescent labeling of single-cell preparations of adherent endometrial cells revealed that cells that were labeled with CD14 were also labeled with CD68 (Fig. 7).

\section{Discussion}

Results presented here indicate that pregnancy in the cow, as in other species, is characterized by changes in immune cell populations in the periphery and uterus. During early pregnancy, at days 33-34 of gestation, there was an increase in the proportion of peripheral blood lymphocytes that were $\mathrm{CD} 4{ }^{+} \mathrm{CD} 25^{+}$cells. These cells, which could be analogous to the $T_{\text {reg }}$ cells described as increasing during pregnancy in mice and humans (Aluvihare et al. 2004, Somerset et al. 2004), were also present in higher amounts in preparturient cows when compared with nonpregnant cows. Late pregnancy was also associated with an increase in the proportion of $\gamma \delta \mathrm{T}$ cells in peripheral blood and a tendency for a decrease in the proportion of cells (presumably monocytes) positive for CD68. The most striking change associated with pregnancy was large-scale recruitment of macrophages positive for CD68 and CD14 to the endometrial stroma.

Pregnancy-associated changes in immune cell populations are likely to be important for protection of the conceptus from maternal immune attack or for removal of cellular debris and microorganisms from the uterus following parturition. The observation that pregnancy causes changes in immune function in the cow that parallel what is seen in other species suggests that the trophoblast-maternal immunological relationship in species with epitheliochorial placentae is not an inert one, as has been implied (Moffett \& Loke 2006), but one characterized by immunological adaptation. 

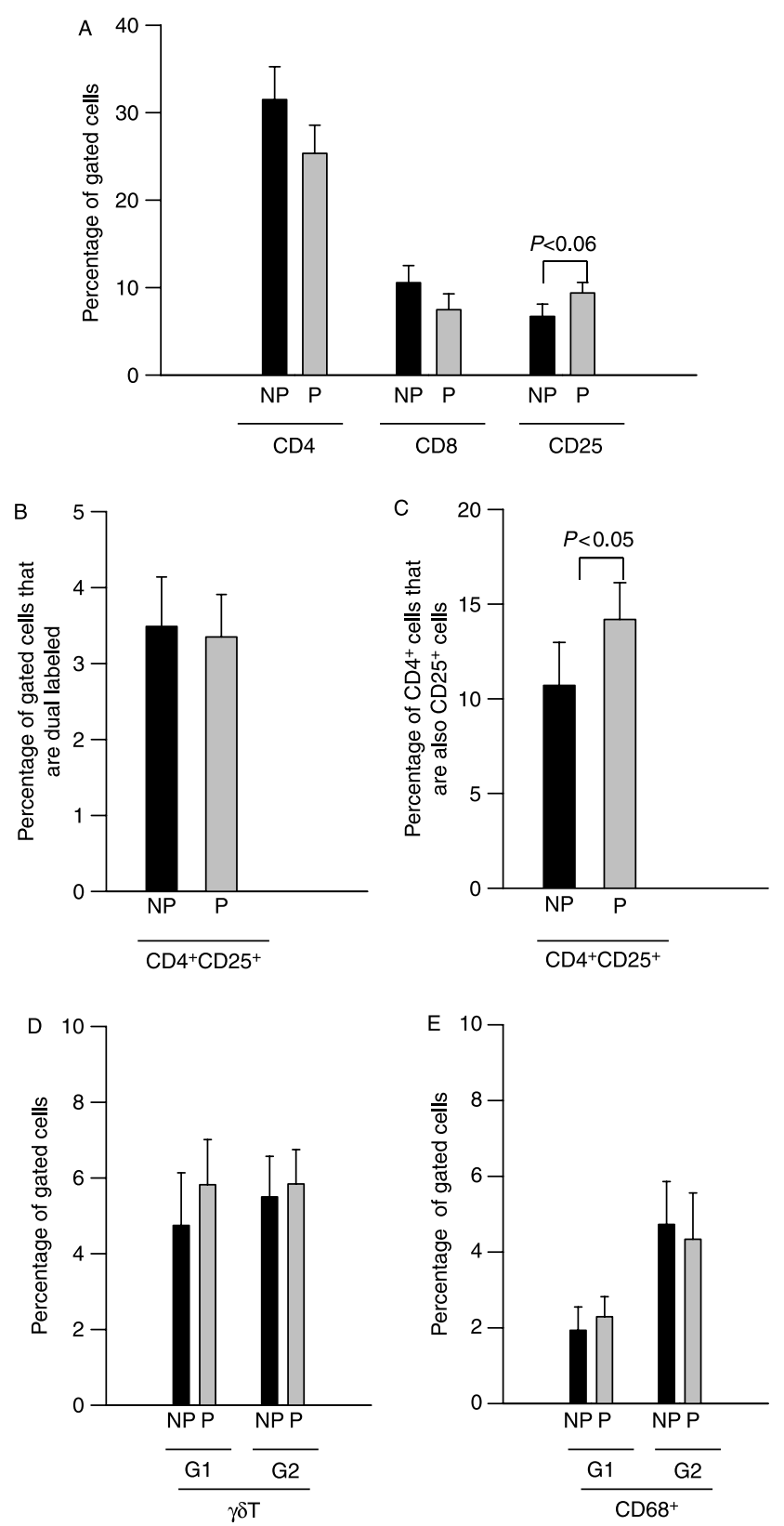

Figure 2 Effect of pregnancy status at days 33-34 after insemination on populations of peripheral blood mononuclear cells as determined by flow cytometry. Data are least-squares means \pm S.E.M. for results for nonpregnant (NP) and pregnant cows (P). (A) Percentage of cells in the lymphocyte gate positive for CD4, CD8, and CD25. (B) Percentage of cells in the lymphocyte gate that are positive for both CD4 and CD25. (C) Percentage of $\mathrm{CD} 4{ }^{+}$cells that are also CD25 $5^{+}$. (D) Percentage of cells in the lymphocyte gate (G1) and monocyte gate (G2) that are positive for $\gamma \delta T$. (E) Percentage of cells in the lymphocyte gate (G1) and monocyte gate (G2) that are positive for CD68.

At both days 33-34 and late pregnancy, there were changes in the population of $\mathrm{CD} 4{ }^{+} \mathrm{CD} 25^{+}$cells in peripheral blood. At days 33-34, this change reflected an increased proportion of $\mathrm{CD} 4^{+}$cells that expressed $\mathrm{CD} 25^{+}$. In preparturient cows, there was an increase in
$\mathrm{CD} 4{ }^{+} \mathrm{CD} 25^{+}$cells that resulted from an increase in the relative number of $\mathrm{CD}^{+}$in the periphery and an increase in the proportion of $\mathrm{CD}^{+}$cells that were positive for CD25. In both women and mice, a subpopulation of $\mathrm{CD} 4{ }^{+} \mathrm{CD} 25^{+}$that expresses the transcription factor FOXP3 is increased in peripheral blood during pregnancy (Aluvihare et al. 2004, Somerset et al. 2004). These cells have been identified as $T_{\text {reg }}$ cells that can secrete cytokines such as IL4 that inhibit activation of cytotoxic $\mathrm{T}$ cells against alloantigens (Mjösberg et al. 2007). The importance of $T_{\text {reg }}$ cells for pregnancy success is indicated by the observation that the percentage of $\mathrm{CD}^{+}{ }^{+} \mathrm{CD} 25^{+}$cells in PBMCs is reduced in women with unexplained recurrent spontaneous abortion (Yang et al. 2008). In mice, depletion of $\mathrm{CD}^{+} 5^{+}$cells decreased the ability of the female to sustain pregnancy (Aluvihare et al. 2004). It is not clear from the present results whether some or all of the $\mathrm{CD} 4{ }^{+} \mathrm{CD} 25^{+}$seen in peripheral blood of cows are $\mathrm{T}_{\text {reg }}$ cells. Antibodies to bovine FOXP3 are not available and several unsuccessful attempts were made to identify antibodies raised against FOXP3 in other species that crossreact with bovine.

The immune changes coincident with pregnancy seen here do not represent the earliest such changes in pregnancy. Ruminant species are unique among mammals in that they have evolved to use a type I interferon (interferon- $\tau$ ) as the trophoblast signal that inhibits endometrial prostaglandin $\mathrm{F}-2 \alpha$ synthesis and allows prolonged lifespan of the corpus luteum (Roberts et al. 2003). Interferon- $\tau$ has retained its immunomodulatory properties and changes in the expression of interferonstimulated genes (ISG) have been described in PBMCs in cattle as early as day 16 of gestation (Han et al. 2006, Gifford et al. 2007). By day 32 of pregnancy, expression of ISG15 in blood cells was similar to that for nonpregnant cows (Han et al. 2006), but it cannot be ruled out that changes in PBMCs seen at days 33-34 in the present study were caused by interferon- $\tau$ secretion by the conceptus earlier in pregnancy.

It was hypothesized that the relative number of $\gamma \delta \mathrm{T}$ cells in peripheral blood would decline during pregnancy, especially in the preparturient period, because of recruitment to the uterus. Indeed, accumulation of $\gamma \delta \mathrm{T}$ cells in the endometrium is a characteristic of pregnancy in humans (Mincheva-Nilsson et al. 1992, 1997), mice (Heyborne et al. 1992), and sheep (Lee et al. 1992, Meeusen et al. 1993, Majewski et al. 2001). In contrast to our hypothesis, the relative number of $\gamma \delta \mathrm{T}$ cells in peripheral blood was not affected by pregnancy status at days 33-34 after insemination and was higher for preparturient cows than for nonpregnant cows. An increase in the relative number of $\gamma \delta \mathrm{T}$ cells in peripheral blood 3 weeks before parturition followed by decrease to initial values at the time of parturition has been noted by others (Van Kampen \& Mallard 1997). 

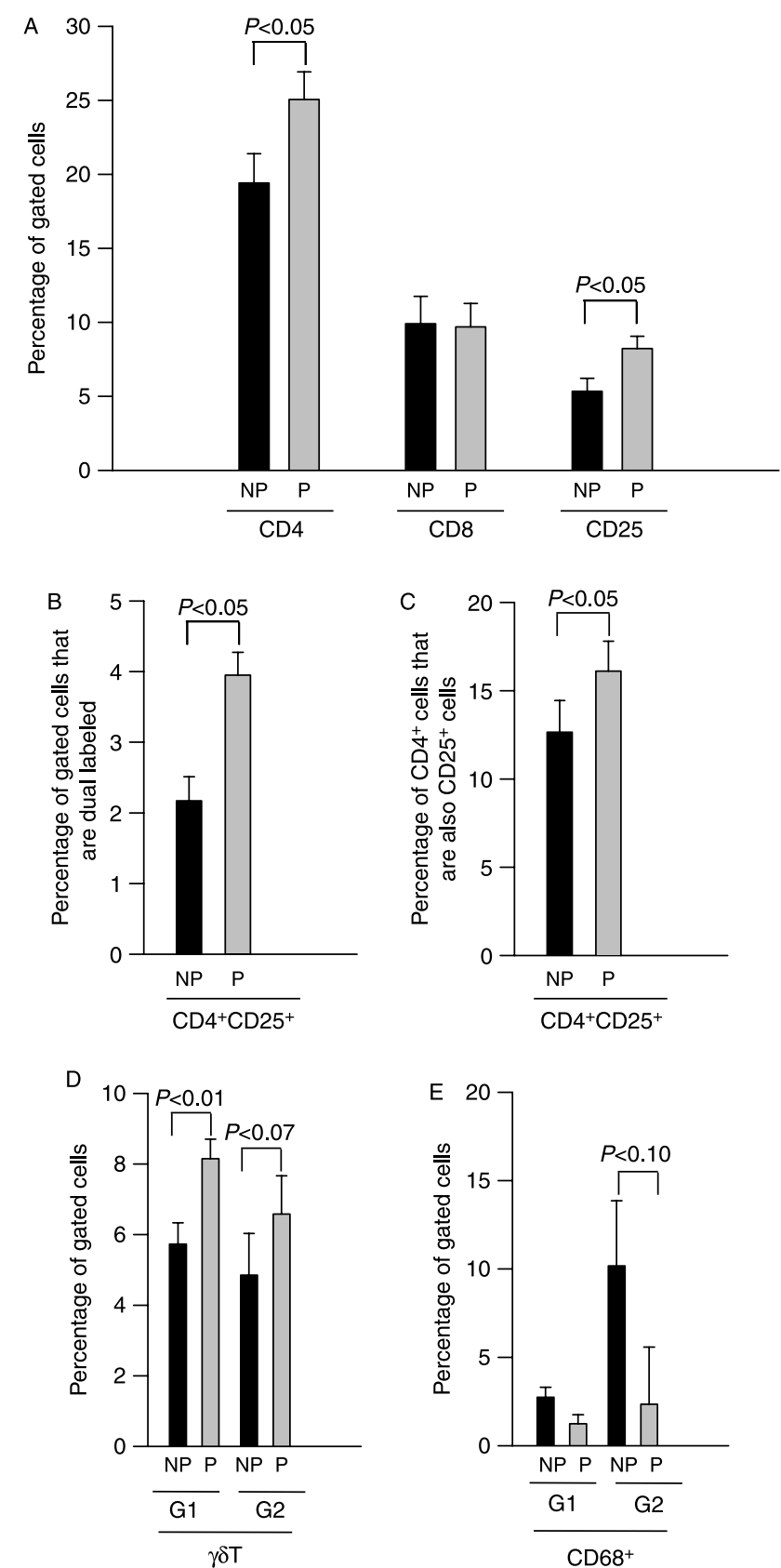

Figure 3 Differences in the peripheral blood mononuclear cell populations between nonpregnant (NP) and preparturient cows (P) as determined by flow cytometry. Data are least-squares means \pm S.E.M. (A) Percentage of cells in the lymphocyte gate positive for CD4, CD8, and CD25. (B) Percentage of cells in the lymphocyte gate that are positive for both CD4 and CD25. (C) Percentage of $\mathrm{CD}^{+}{ }^{+}$cells that are also $\mathrm{CD}^{+} 5^{+}$(D) Percentage of cells in the lymphocyte gate (G1) and monocyte gate (G2) that are positive for $\gamma \delta$ T. (E) Percentage of cells in the lymphocyte gate $(\mathrm{G} 1)$ and monocyte gate $(\mathrm{G} 2)$ that are positive for CD68.

The recruitment of macrophages to the pregnant uterus has been described in many species such as humans (Heikkinen et al. 2003, Cupurdija et al. 2004, Kim et al. 2007), mice (Hunt et al. 1985), and sheep (Tekin \& Hansen 2004). Present results indicate that this process occurs in the cow also with numbers increasing by days 54-100 of pregnancy. For preparturient cows, there was a decline in the relative number of $\mathrm{CD} 68^{+}$ cells in peripheral blood and this change could reflect increased recruitment to the uterus. That the $\mathrm{CD}_{68}{ }^{+}$ cells in endometrial stroma are macrophages is indicated by the co-expression of CD14, which is also expressed in tissue macrophages such as in pulmonary alveoli (Yang et al. 1995). The signals for movement of monocytes from the blood to the uterus and their differentiation once resident in the endometrium are not known. Mouse trophoblast can cause migration of blood monocytes in vitro (Fest et al. 2007) and change monocyte cytokine prolife and activation in response to lipopolysaccharide.

The accumulation of large number of macrophages in the endometrium during pregnancy strongly suggests an important role for these cells in the uterus. One possibility is that uterine macrophages participate in parturition by promoting placental detachment. Evidence for immunological participation in the parturition process is indicated by the increased incidence of retained placentae in cows, which share MHC class I antigens with their conceptus (Joosten et al. 1991). Retained placenta in cattle has also been related to decreased activity of macrophages in the placentomal area (Miyoshi et al. 2002). The postpartum uterus is characterized by abundant lochia and microorganisms (Lewis 1997, Thatcher et al. 2006), and macrophages may participate in the involution process whereby these materials are removed in the postpartum period. Finally, it may be that macrophages function during pregnancy to promote survival of the allogeneic conceptus. In human, placental macrophages express markers of alternative activation (Cupurdija et al. 2004) and markers such as stabilin-1 that have been suggested to be involved in an anti-inflammatory function (Politz et al. 2002). It has been proposed that clearance of apoptotic trophoblast cells by uterine macrophages alters macrophage cytokine secretion to reduce inflammation and promote conceptus survival (Mor et al. 2006). Also, macrophage-associated stabilin-1 can bind to and process placental lactogen in vitro, suggesting regulation of extracellular levels of placental lactogen by alternatively activated macrophages (Kzhyshkowska et al. 2008).

There is evidence that the preparturient dairy cow is immunosuppressed with a decline in the number of $\mathrm{CD}^{+}, \mathrm{CD}^{+}$, and $\gamma \delta$ cells in peripheral blood (Van Kampen \& Mallard 1997, Kimura et al. 1999, 2002) and reduced proliferation and interferon- $\gamma$ secretion by mitogen-stimulated lymphocytes (Detilleux et al. 1995, Nonnecke et al. 2003). There was little evidence of immunosuppression in the present study. Preparturient cows did not have reduced proportions of $\mathrm{CD}^{+}$cells in peripheral blood when compared with nonpregnant cows and the number of $\mathrm{CD}^{+}{ }^{+}$and $\gamma \delta \mathrm{T}$ cells was increased. Karcher et al. (2008) also did not observe declines in $\mathrm{CD}^{+}$cells as parturition approached and 


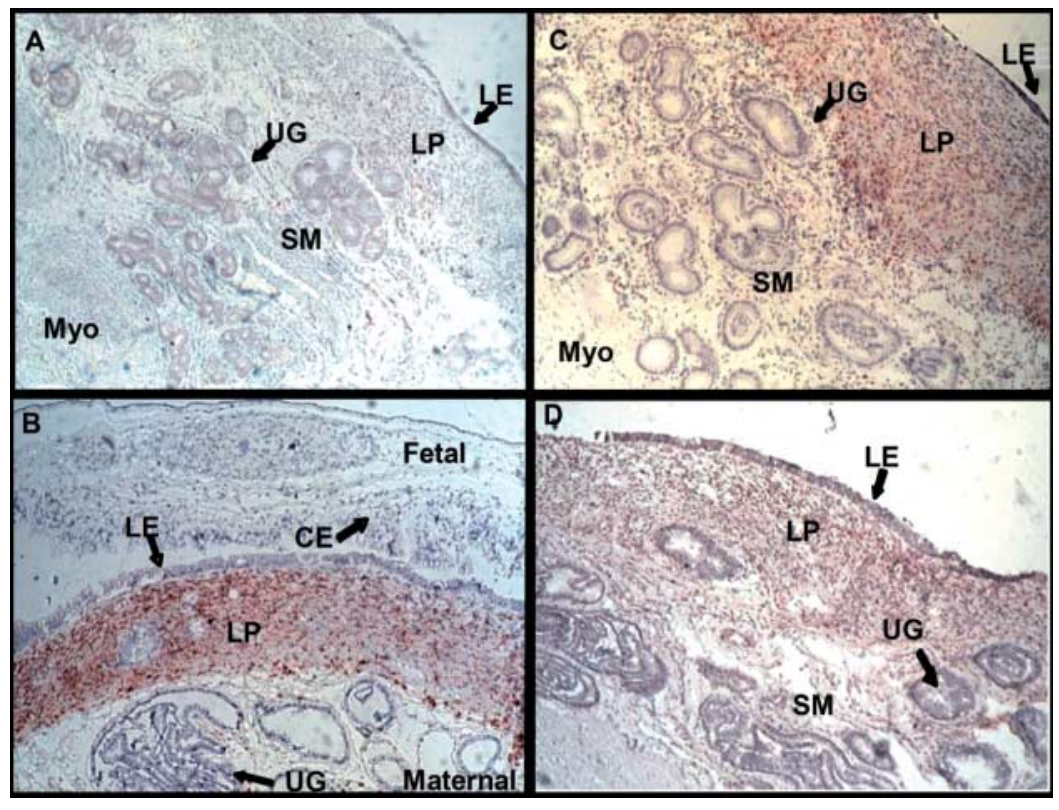

Figure 4 Immunolocalization of cells positive for (A-C) CD68 and (D) CD14 in bovine endometrium. Represented are sections of endometrium from a nonpregnant cow $(\mathrm{A})$ and pregnant cows at days 75 (C) and 209 (B and D) of pregnancy. Note that fetal chorion has been retained for panel B only. Brown, immune reaction product; blue, hematoxylin counterstain. LE, luminal epithelium; LP, lamina propria; Myo, myometrium; UG, uterine gland; SM, submucosa; $\mathrm{CE}$, chorionic epithelium. there was a tendency for an increase in the proportion of $\gamma \delta T$ cells as parturition approached. In the present study, the only direct evidence for reduced immune competency in preparturient cows was the tendency for a reduction in the number of $\mathrm{CD}^{+} 8^{+}$cells. It is possible, however, that the increase in the number of $\mathrm{CD} 4{ }^{+} \mathrm{CD} 25^{+}$and $\gamma \delta \mathrm{T}$ cells seen in preparturient cows is an indication for immunosuppression in the preparturient period if some of these cells are $\mathrm{T}_{\text {reg }}$ cells.

Moffett \& Loke (2006) compared the maternal-fetal immunological relationship in species with epitheliochorial placenta to the immunological relationship between commensal bacteria and host organisms. In this view, little immunological recognition of the conceptus occurs unless the epithelial barrier is breached. The current results indicate that development of the epitheliochorial placenta during evolution has not changed the occurrence of several immunological adjustments to pregnancy. Like the human and mouse, there is an increase in $\mathrm{CD} 4{ }^{+} \mathrm{CD} 25^{+}$lymphocytes in peripheral blood and accumulation of macrophages in the endometrium. These pregnancy-associated changes in immune function indicate that, rather than being an immunologically inert tissue, the bovine conceptus is a tissue whose presence requires maternal immunological adjustments. These adjustments can be detected as early as day 16 (Han etal.2006, Gifford etal.2007), are present at days 33-34 of pregnancy, and are still occurring close to parturition. Thus, the maternal immune system in the cow is constantly adjusting to the conceptus. Given this pattern of immunological change, which is also seen in other species with epitheliochorial placenta (Lee et al. 1992, Yu et al. 1993, Baker et al. 1999, Majewski et al. 2001, Tekin \& Hansen 2004), it seems more likely that evolution of a epitheliochorial placenta occurred because of increases in efficiency of placental transport (Leiser et al. 1997) or increased maternal control over the vascular supply to the conceptus (Mess \& Carter 2007) rather than to change the fundamental characteristics of the maternal-fetal immunological relationship.

\section{Materials and Methods}

\section{Materials}

Tissue culture medium-199 (TCM-199), normal goat serum, BSA Fraction-V, Dulbecco's PBS (DPBS), and Hoescht 33342 were purchased from Sigma-Aldrich. The Fico-Lite 1077 was from Atlanta Biologicals (Norcross, GA, USA). The Zenon Alexa Fluor 488 mouse IgG1 labeling kit, Zenon Alexa Fluor R-phycoerythrin mouse IgG1 labeling kit, Zenon Alexa Fluor 647 mouse IgG2a labeling kit, and the mounting medium (Prolong Antifade Kit) were obtained from Invitrogen Molecular Probes. Paraformaldehyde $(8 \%, \mathrm{w} / \mathrm{v})$ was purchased from Electron Microscopy Sciences (Fort Washington, PA, USA).

Hybridoma cells producing monoclonal antibodies against bovine CD8 (clone 7C2) and ovine $\gamma \delta \mathrm{T}$ (clone 86D) were purchased from European Type Cell Culture Collection (Salisbury, UK). These monoclonal antibodies were obtained as culture supernatants of hybridoma cell cultures prepared by the Hybridoma Core Laboratory of the University of Florida Interdisciplinary Center for Biotechnology Research.

Mouse anti-human CD68 (clone EBM11; clarified ascites fluid, $2.3 \mu \mathrm{g} / \mathrm{ml}$ ) was obtained from Biomeda (Foster City, CA, USA); mouse anti-bovine CD14 (clone MM61A; clarified ascites fluid, $10 \mu \mathrm{g} / \mathrm{ml}$ ), mouse anti-bovine CD4 (clone CATC 138A; clarified ascites fluid, $10 \mu \mathrm{g} / \mathrm{ml}$ ), and mouse anti-bovine bovine CD25 (clone CATC 108A; clarified ascites fluid, $10 \mu \mathrm{g} / \mathrm{ml}$ ) were from VMRD (Pullman, WA, USA). Control mouse ascites fluid (clarified, clone NS1) was from Sigma-Aldrich. Normal goat serum was purchased from Pel-Freez Biologicals (Rogers, AR, 


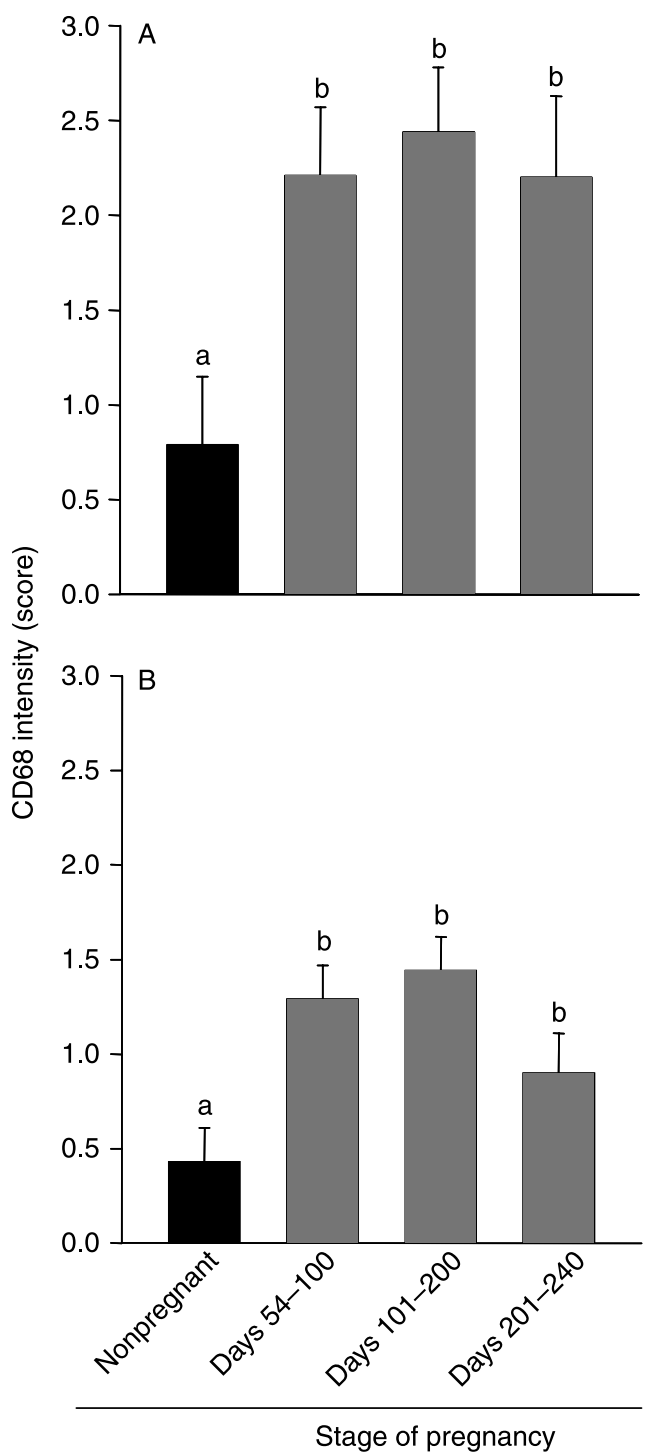

Figure 5 Effect of pregnancy status on the intensity of staining for CD68 in the lamina propria (A) and submucosa (B) of the endometrium. Shown are data for nonpregnant cows $(n=7)$ and pregnant cows at days 54-100 $(n=7), 101-200(n=8)$, and $201-240$ of pregnancy $(n=5)$. Intensity was estimated subjectively using a scoring system from 0 to 5 . Data are least-squares means \pm S.E.M. Bars with different letters are different from each other $(P<0.05)$.

USA). The Histoscan Monoclonal Detector kit and mounting medium were obtained from Biomeda. Tissue freezing medium was obtained from Biotech Medical Corporation (Kuala Lampur, Malaysia). Lab-Tek Glass Chamber Slides were obtained from Electron Microscopy Sciences (Hatfield, PA, USA).

\section{Flow cytometric analysis of PBMCs}

\section{Animals}

Cows were maintained at the University of Florida Dairy Research Unit at Hague, Florida. The first experiment was designed to determine the differences in the peripheral blood lymphocyte populations between the nonpregnant and pregnant cows at days 33-34 of gestation. A total of 33 lactating Holstein cows were subjected to timed artificial insemination using a modified Presynch-OvSynch procedure (Brusveen et al. 2008) for insemination at days $233 \pm 21$ after calving (range 127-389). Cows were diagnosed for pregnancy using transrectal ultrasound examination at days 33-34 after insemination and a blood sample was collected by coccygeal venipuncture into heparinized tubes and used for flow cytometry. Blood samples were collected from a total of 18 nonpregnant and 15 pregnant cows.

The second experiment was designed to determine the differences between the nonpregnant and preparturient cows. A coccygeal blood sample was collected from a total of eight nonpregnant cows that were non-lactating and at random stages of the estrous cycle and from eight pregnant cows that were nonlactating and were at an average of $281.3 \pm 2.9$ days of gestation (range 273-289). The preparturient cows were at an average of $4.9 \pm 1.7$ days before parturition (range $1-14$ days).

\section{Isolation of PBMCS}

Blood (10 ml) was centrifuged at $600 \mathrm{~g}$ for $30 \mathrm{~min}$ to obtain the buffy coat. This layer was mixed with $2 \mathrm{ml}$ TCM-199 and the cell suspension was transferred to the top of $2 \mathrm{ml} \mathrm{Fico/Lite}$ LymphoH placed in a $15 \mathrm{ml}$ conical tube. Cells were centrifuged at $600 \mathrm{~g}$ for $30 \mathrm{~min}$. Mononuclear cells were collected at the top of the Fico/Lite, centrifuged at $600 \mathrm{~g}$ for $10 \mathrm{~min}$, resuspended in DPBS, and used to determine cell concentration and viability by trypan blue exclusion using a hemacytometer. The cells were then resuspended to a final concentration of $5 \times 10^{7} / \mathrm{ml}$.

\section{Flow cytometry}

The cells $\left(5 \times 10^{6}\right)$ were placed into $13 \times 100 \mathrm{~mm}$ polyethylene tubes in staining buffer (DPBS supplemented with $0.1 \%(\mathrm{w} / \mathrm{v})$ BSA and $0.1 \%(\mathrm{w} / \mathrm{v})$ sodium azide), washed twice with $2 \mathrm{ml}$ staining buffer, and resuspended in the smallest volume possible with staining buffer. The cells were then stained for single-color analysis using anti- $\gamma \delta$ and anti-CD68 antibodies and for dual-color analysis with anti-CD4 and anti-CD8 and anti-CD4 and anti-CD25. A mouse IgG was used in the same dilution of the primary antibody as a control to nonspecific antibody staining. The antibodies, including the IgG control, were tagged with Fab fragments against mouse IgG conjugated to Alexa Flour 488, Alexa Flour R-phycoerythrin and Alexa Flour 647 using the Zenon Mouse Labeling IgG kits as per manufacturer's instructions. The labeled antibody complex was then diluted in the staining buffer to a final concentration of $10 \mu \mathrm{g} / \mathrm{ml}$ at room temperature for $30 \mathrm{~min}$. After incubation, the samples were washed with $2 \mathrm{ml}$ staining buffer, and resuspended with DPBS containing 4\% (w/v) paraformaldehyde for fixation. Before analysis, the cells were washed once with $1 \mathrm{ml}$ staining buffer and resuspended in $300 \mu$ staining buffer. The flow cytometry profiles were obtained on Fluorescent Analysis Cell Sorter 'FACSCalibur' using CELLQuest flow cytometry software (Becton-Dickinson, Franklin Lakes, NJ, USA). The cell populations analyzed were gated on the basis of forward and side scatter at the lymphocyte and monocyte regions. 

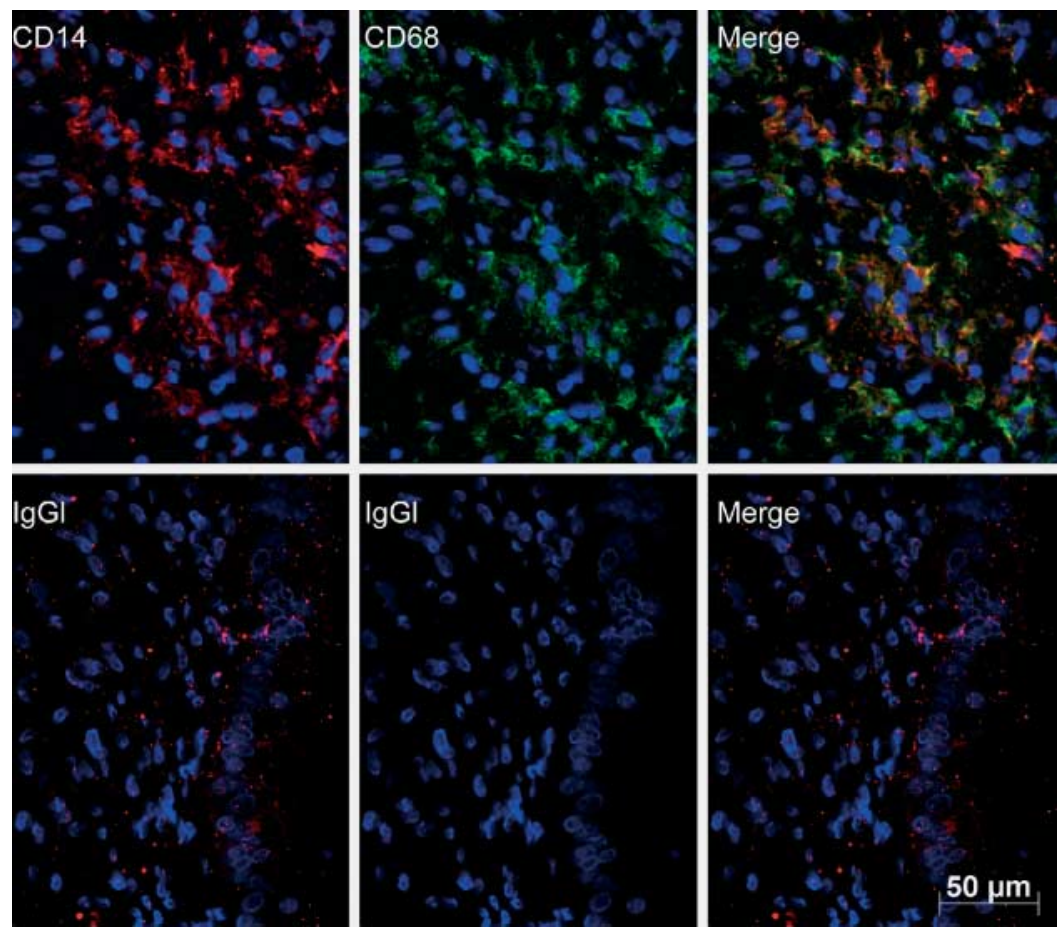

Figure 6 Co-localization of CD68 and CD14 in endometrium at day 209 of pregnancy. The top panels represent sections that were dual labeled with anti-CD14 (red) and anti-CD68 (green). Blue indicates nuclear stain. The bottom panels represent sections incubated with red- and green-labeled isotype controls.

\section{Immunohistochemistry for CD68 and CD14}

Uteri were obtained from pregnant and nonpregnant cows of various breeds at a local abattoir. Fetal crown-rump length was measured to estimate the fetal age (Noden \& de Lahunta 1990). Reproductive tracts from nonpregnant cows were used only if a corpus luteum was present. Tissues from a total of 20 pregnant cows (estimated fetal ages ranging from 54 to 240 days of pregnancy) and 7 nonpregnant cows were collected. Samples of intercotyledonary uterine endometrium ipsilateral to the corpus luteum were snap frozen in Tissue-Tek OCT embedding compound. Tissues from pregnant and nonpregnant cows were processed in parallel to avoid confounding physiological stage with procedural replicate.

For immunohistochemistry, $5 \mu \mathrm{m}$ tissue sections were prepared with a cryostat microtome. Sections were placed onto precleaned glass slides, fixed in ice-cold acetone for $10 \mathrm{~min}$ and air dried. The sections were rehydrated in histochemistry buffer at $4{ }^{\circ} \mathrm{C}\left(10 \mathrm{mM} \mathrm{NaPO}_{4}(\mathrm{pH} 7.4)\right.$ containing $0.9 \%(\mathrm{w} / \mathrm{v}) \mathrm{NaCl}$ supplemented with $1 \%(\mathrm{v} / \mathrm{v})$ normal goat serum) for $30 \mathrm{~min}$.
Procedures for immunohistochemistry were carried out according to the manufacturer's instructions. Briefly, sections were sequentially incubated with peroxidase-blocking buffer (histochemistry buffer with $0.3 \%(\mathrm{v} / \mathrm{v}) \mathrm{H}_{2} \mathrm{O}_{2}$ ) for 5 min and washed three times in histochemistry buffer. The tissue conditioner supplied in the kit was applied to the samples for 4 min before incubation with primary antibody overnight at $4{ }^{\circ} \mathrm{C}$; primary antibodies used were anti-CD68 $(2.3 \mu \mathrm{g} / \mathrm{ml})$ and anti-CD14 $(10 \mu \mathrm{g} / \mathrm{ml})$ in histochemistry buffer. As controls, other sections were incubated with $\operatorname{lgG}(10 \mu \mathrm{g} / \mathrm{ml})$ in histochemistry buffer. Slides were then sequentially incubated with secondary antibody (biotinylated anti-mouse immunoglobulin as supplied in the kit) for $30 \mathrm{~min}$, streptavidin-alkaline phosphatase reagent (from kit) for $30 \mathrm{~min}$, and hematoxylin (as supplied in the kit) for $2 \mathrm{~min}$. Slides were washed under tap water, cover slips were mounted, and the slides were examined for staining using light microscopy.

The concentration of $\mathrm{CD}^{+} 8^{+}$cells in the endometrial stroma was estimated subjectively according to a scale ranging from 0 (no positive cells) to 5 (very intense accumulation of positive cells). Evaluation was performed blindly with respect to treatment.
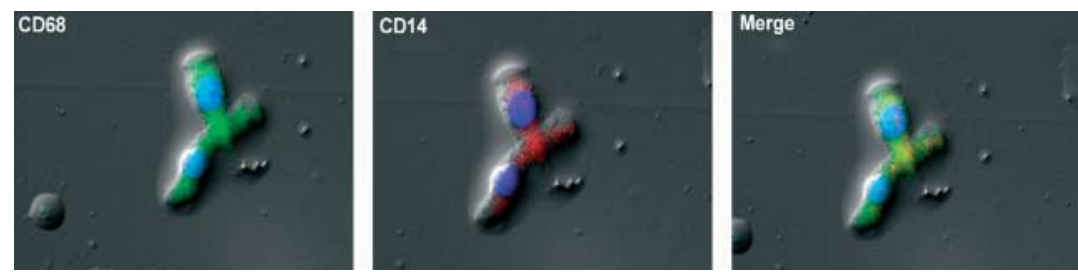

Figure 7 Co-localization of CD68 and CD14 in adherent cells isolated from dispersed endometrial cells from a pregnant cow at day 166 of pregnancy. Cells were labeled with anti-CD14 (red), anti-CD68 (green), and Hoescht 33342 (blue) for nuclei. Photomicrographs represent images obtained using differential interference contrast as well as fluorescence with the green and blue filters (CD68), red and blue filters (CD14), or with all three colors merged (Merge). 


\section{Two-color immunofluorescence for CD68 and CD14}

Uterine sections were prepared as described previously. Sections were incubated with blocking buffer (DPBS supplemented with $20 \%(\mathrm{v} / \mathrm{v})$ goat serum) for $20 \mathrm{~min}$ followed by incubation overnight at $4{ }^{\circ} \mathrm{C}$ with anti-CD68 $(2.3 \mu \mathrm{g} / \mathrm{ml})$, antiCD14 $(10 \mu \mathrm{g} / \mathrm{ml})$, and isotype controls $(10 \mu \mathrm{g} / \mathrm{ml})$ labeled using the Zenon labeling system as described previously. The sections were then washed three times for 5 min using PBS and then labeled with Hoescht 33342 reagent $(2.3 \mu \mathrm{g} / \mathrm{ml})$ for $15 \mathrm{~min}$. Sections were washed an additional three times for 5 min each, cover slips mounted using Prolong Antifade reagent, and slides examined using a Zeiss Axioplan 2 epifluorescence microscope (Zeiss, Gottingen, Germany) with a $40 \times$ objective and using Zeiss filter set 02 (DAPI filter), Zeiss filter set 03 (FITC filter), and Zeiss filter set 15 (rhodamine filter). Digital images were acquired using AxioVision software (Zeiss) and a high-resolution black and white Zeiss AxioCam MRm digital camera.

\section{Two-color immunofluorescence for CD68 and CD14 in endometrial adherent cells}

Two-color immunofluorescence was performed using preparations of dispersed adherent cells from endometrium of a pregnant cow at day 166 of pregnancy. The uterus was obtained from a local abattoir and transported to the laboratory on ice $(\sim 2 \mathrm{~h})$. A sample of the intercaruncular region was taken for isolation of stromal endometrial cells. Endometrial cells were removed from intercaruncular areas of the endometrium by mechanically scraping the inner surface of the endometrium with a sterile surgical blade. Cell scrapings were collected into a $50 \mathrm{ml}$ sterile culture tube containing $50 \mathrm{ml}$ TCM-199 supplemented with type I collagenase at $150 \mathrm{U} / \mathrm{ml}$. Cells were incubated at $37^{\circ} \mathrm{C}$ for $1 \mathrm{~h}$ under gentle rotation. Cells in suspension were then filtered through a sterile $100 \mu \mathrm{m}$ cell strainer into $50 \mathrm{ml}$ sterile culture tubes and centrifuged at $110 \mathrm{~g}$ for $5 \mathrm{~min}$. The cell pellet was resuspended with $5 \mathrm{ml}$ TCM-199 supplemented with $10 \%$ $(\mathrm{v} / \mathrm{v})$ fetal bovine serum and the cell number was determined using a hemacytometer. The cell suspension was placed into eight-well sterile chamber slides (Lab-Tek Glass Chamber Slides; Electron Microscopy Sciences) with a cover and incubated at $37^{\circ} \mathrm{C}$ for $2 \mathrm{~h}$ to allow cells to adhere. The wells were washed three times with DPBS to eliminate non-adherent cells. The remaining adherent cells were fixed in DPBS containing 4\% (w/v) paraformaldehyde for $15 \mathrm{~min}$. The wells were washed three times in DPBS and two-color immunofluorescence staining was performed as described above.

\section{Statistical analysis}

Data were analyzed by least-squares ANOVA using the General Linear Model procedure of SAS (SAS for Windows, version 9.3; SAS Institute Inc., Cary, NC, USA). For the flow cytometry studies, the model included the effect of physiological status (pregnant versus nonpregnant), date samples were collected (i.e., replicate), and the interaction. For intensity of CD68 staining in endometrium, cows were grouped into four groups based on the stage of pregnancy (nonpregnant, $n=7$; days 54-100 of pregnancy, $n=7$; days 101-200 of pregnancy, $n=8$; and days 201-240 of pregnancy, $n=5$ ). The mathematical model included the effect of stage of pregnancy.

\section{Declaration of interest}

There is no conflict of interest that would prejudice its impartiality.

\section{Funding}

Research was supported by the Florida Agricultural Experiment Station and by a grant to L J O from CAPES/Fulbright (Grant 2062046).

\section{Acknowledgements}

The authors would like to thank the following for their assistance with the project: Dr Sally Johnson, William Rembert, Luciano Bonilla, Dr Robson Giglio, Dr William W Thatcher, Flavio Slivestre, Dr Carlos Risco, the Flow Cytometry Facility, and Hybridoma Core Laboratory of the University of Florida Interdisciplinary Center for Biotechnology Research, and Central Packing, Center Hill, Florida.

\section{References}

Aluvihare VR, Kallikourdis M \& Betz AG 2004 Regulatory T cells mediate maternal tolerance to the fetus. Nature Immunology 5 266-271.

Baker JM, Bamford AI \& Antczak DF 1999 Modulation of allospecific CTL responses during pregnancy in equids: an immunological barrier to interspecies matings? Journal of Immunology 162 4496-4501.

Bilinski MJ, Thorne JG, Oh MJ, Leonard S, Murrant C, Tayade C \& Croy BA 2008 Uterine NK cells in murine pregnancy. Reproductive Biomedicine Online 16 218-226.

Brusveen DJ, Cunha AP, Silva CD, Cunha PM, Sterry RA, Silva EP, Guenther JN \& Wiltbank MC 2008 Altering the time of the second gonadotropin-releasing hormone injection and artificial insemination (Al) during Ovsynch affects pregnancies per $\mathrm{Al}$ in lactating dairy cows. Journal of Dairy Science 91 1044-1052.

Cupurdija K, Azzola D, Hainz U, Gratchev A, Heitger A, Takikawa O, Goerdt S, Wintersteiger R, Dohr G \& Sedlmayr P 2004 Macrophages of human first trimester decidua express markers associated to alternative activation. American Journal of Reproductive Immunology 51 117-122.

Detilleux JC, Kehrli ME Jr, Stabel JR, Freeman AE \& Kelley DH 1995 Study of immunological dysfunction in preparturient Holstein cattle selected for high and average milk production. Veterinary Immunology and Immunopathology 44 251-267.

Fest S, Aldo PB, Abrahams VM, Visintin I, Alvero A, Chen R, Chavez SL, Romero R \& Mor G 2007 Trophoblast-macrophage interactions: a regulatory network for the protection of pregnancy. American Journal of Reproductive Immunology 57 55-66.

Gifford CA, Racicot K, Clark DS, Austin KJ, Hansen TR, Lucy MC, Davies CJ \& Ott TL 2007 Regulation of interferon-stimulated genes in peripheral blood leukocytes in pregnant and bred, nonpregnant dairy cows. Journal of Dairy Science 90 274-280.

Gorivodsky M, Torchinsky A, Zemliak I, Savion S, Fein A \& Toder V 1999 TGF $\beta 2$ mRNA expression and pregnancy failure in mice. American Journal of Reproductive Immunology 42 124-133.

Han H, Austin KJ, Rempel LA \& Hansen TR 2006 Low blood ISG15 mRNA and progesterone levels are predictive of non-pregnant dairy cows. Journal of Endocrinology 191 505-512.

Hanna N, Hanna I, Hleb M, Wagner E, Dougherty J, Balkundi D, Padbury J \& Sharma S 2000 Gestational age-dependent expression of IL-10 and its receptor in human placental tissues and isolated cytotrophoblasts. Journal of Immunology 164 5721-5728. 
Heikkinen J, Mottonen M, Komi J, Alanen A \& Lassila O 2003 Phenotypic characterization of human decidual macrophages. Clinical and Experimental Immunology 131 498-505.

Heyborne KD, Cranfill RL, Carding SR, Born WK \& O'Brien RL 1992 Characterization of $\gamma \delta \mathrm{T}$ lymphocytes at the maternal-fetal interface. Journal of Immunology 149 2872-2878.

Hunt JS, Manning LS, Mitchell D, Selanders JR \& Wood GW 1985 Localization and characterization of macrophages in murine uterus. Journal of Leukocyte Biology 38 255-265.

Joosten I, Sanders MF \& Hensen EJ 1991 Involvement of major histocompatibility complex class I compatibility between dam and calf in the aetiology of bovine retained placenta. Animal Genetics 22 455-463.

Van Kampen C \& Mallard BA 1997 Effects of peripartum stress and health on circulating bovine lymphocyte subsets. Veterinary Immunology and Immunopathology 59 79-91.

Karcher EL, Beitz DC \& Stabel JR 2008 Parturition invokes changes in peripheral blood mononuclear cell populations in Holstein dairy cows naturally infected with Mycobacterium avium subsp. paratuberculosis. Veterinary Immunology and Immunopathology 124 50-62.

Kim JS, Romero R, Cushenberry E, Kim YM, Erez O, Nien JK, Yoon BH, Espinoza J \& Kim CJ 2007 Distribution of $\mathrm{CD}^{+} 4^{+}$and $\mathrm{CD}^{+} 8^{+}$ macrophages in the placental bed and basal plate of women with preeclampsia and preterm labor. Placenta 28 571-576.

Kimura K, Goff JP, Kehrli ME Jr \& Harp JA 1999 Phenotype analysis of peripheral blood mononuclear cells in preparturient dairy cows. Journal of Dairy Science 82 315-319.

Kimura K, Goff JP, Kehrli ME Jr, Harp JA \& Nonnecke BJ 2002 Effects of mastectomy on composition of peripheral blood mononuclear cell populations in preparturient dairy cows. Journal of Dairy Science $\mathbf{8 5}$ 1437-1444.

Kzhyshkowska J, Gratchev A, Schmuttermaier C, Brundiers H, Krusell L, Mamidi S, Zhang J, Workman G, Sage EH, Anderle C et al. 2008 Alternatively activated macrophages regulate extracellular levels of the hormone placental lactogen via receptor-mediated uptake and transcytosis. Journal of Immunology 180 3028-3037.

Lee CS, Meeusen E, Gogolin-Ewens K \& Brandon MR 1992 Quantitative and qualitative changes in the intraepithelial lymphocyte population in the uterus of nonpregnant and pregnant sheep. American Journal of Reproductive Immunology 28 90-96.

Leiser R, Krebs C, Ebert B \& Dantzer V 1997 Placental vascular corrosion cast studies: a comparison between ruminants and humans. Microscopy Research and Technique 38 76-87.

Lewis GS 1997 Uterine health and disorders. Journal of Dairy Science $\mathbf{8 0}$ 984-994.

Mackler AM, Green LM, McMillan PJ \& Yellon SM 2000 Distribution and activation of uterine mononuclear phagocytes in peripartum endometrium and myometrium of the mouse. Biology of Reproduction 62 1193-1200.

Majewski AC, Tekin S \& Hansen PJ 2001 Local versus systemic control of numbers of endometrial T cells during pregnancy in sheep. Immunology 102 317-322.

Meeusen E, Fox A, Brandon M \& Lee CS 1993 Activation of uterine intraepithelial $\gamma \delta \mathrm{T}$ cell receptor-positive lymphocytes during pregnancy. European Journal of Immunology 23 1112-1117.

Mess A \& Carter AM 2007 Evolution of the placenta during the early radiation of placental mammals. Comparative Biochemistry and Physiology. Part A, Molecular \& Integrative Physiology 148 769-779.

Mincheva-Nilsson L, Hammarström S \& Hammarström ML 1992 Human decidual leukocytes from early pregnancy contain high numbers of $\gamma \delta^{+}$ cells and show selective down-regulation of alloreactivity. Journal of Immunology 149 2203-2211.

Mincheva-Nilsson L, Kling M, Hammarström S, Nagaeva O, Sundqvist KG, Hammarström ML \& Baranov V $1997 \gamma \delta$ T cells of human early pregnancy decidua. Evidence for local proliferation, phenotypic heterogeneity, and extrathymic differentiation. Journal of Immunology 159 3266-3277.

Miyoshi M, Sawamukai Y \& Iwanaga T 2002 Reduced phagocytotic activity of macrophages in the bovine retained placenta. Reproduction in Domestic Animals 37 53-56.

Mjösberg J, Berg G, Ernerudh J \& Ekerfelt C 2007 CD4 ${ }^{+}$CD25 $5^{+}$regulatory $\mathrm{T}$ cells in human pregnancy: development of a $\mathrm{T}_{\text {reg }}$-MLC-ELISPOT suppression assay and indications of paternal specific $\mathrm{T}_{\text {regs. }}$ Immunology $120456-466$.
Moffett A \& Loke C 2006 Immunology of placentation in eutherian mammals. Nature Reviews Immunology 6 584-594.

Mor G, Straszewski-Chavez SL \& Abrahams VM 2006 Macrophagetrophoblast interactions. Methods in Molecular Medicine 122 149-163.

Murphy SP, Fast LD, Hanna NN \& Sharma S 2005 Uterine NK cells mediate inflammation-induced fetal demise in IL-10-null mice. Journal of Immunology 175 4084-4090.

Nagaeva O, Jonsson L \& Mincheva-Nilsson L 2002 Dominant IL-10 and TGF- $\beta$ mRNA expression in $\gamma \delta$ T cells of human early pregnancy decidua suggests immunoregulatory potential. American Journal of Reproductive Immunology 48 9-17.

Noden DM \& de Lahunta A 1990 Extraembryonic membranes and placentation. In The Embryology of Domestic Animals, pp 47-69. Eds DM Noden \& A de Lahunta. Baltimore: Williams and Wilkins.

Nonnecke BJ, Kimura K, Goff JP \& Kehrli ME Jr 2003 Effects of the mammary gland on functional capacities of blood mononuclear leukocyte populations from preparturient cows. Journal of Dairy Science 86 2359-2368.

Politz O, Gratchev A, McCourt PA, Schledzewski K, Guillot P, Johansson S, Svineng G, Franke P, Kannicht C, Kzhyshkowska J et al. 2002 Stabilin-1 and -2 constitute a novel family of fasciclin-like hyaluronan receptor homologues. Biochemical Journal 362 155-164.

Roberts RM, Ezashi T, Rosenfeld CS, Ealy AD \& Kubisch HM 2003 Evolution of the interferon tau genes and their promoters, and maternal-trophoblast interactions in control of their expression. Reproduction Supplement 61 239-251.

Shigeru S, Akitoshi N, Subaru MH \& Shiozaki A 2008 The balance between cytotoxic NK cells and regulatory NK cells in human pregnancy. Journal of Reproductive Immunology 77 14-22.

Simpson H, Robson SC, Bulmer JN, Barber A \& Lyall F 2002 Transforming growth factor $\beta$ expression in human placenta and placental bed during early pregnancy. Placenta 23 44-58.

Somerset DA, Zheng Y, Kilby MD, Sansom DM \& Drayson MT 2004 Normal human pregnancy is associated with an elevation in the immune suppressive $\mathrm{CD} 5^{+} \mathrm{CD}^{+}{ }^{+}$regulatory T-cell subset. Immunology 112 38-43.

Suzuki T, Hiromatsu K, Ando Y, Okamoto T, Tomoda Y \& Yoshikai Y 1995 Regulatory role of $\gamma \delta \mathrm{T}$ cells in uterine intraepithelial lymphocytes in maternal antifetal immune response. Journal of Immunology 154 4476-4484.

Tafuri A, Alferink J, Möller P, Hämmerling GJ \& Arnold B 1995 T cell awareness of paternal alloantigens during pregnancy. Science 270 630-633.

Tekin S \& Hansen PJ 2004 Regulation of numbers of macrophages in the endometrium of the sheep by systemic effects of pregnancy, local presence of the conceptus, and progesterone. American Journal of Reproductive Immunology 51 56-62.

Thatcher WW, Bilby TR, Bartolome JA, Silvestre F, Staples CR \& Santos JE 2006 Strategies for improving fertility in the modern dairy cow. Theriogenology 65 30-44.

Thomson AJ, Telfer JF, Young A, Campbell S, Stewart CJ, Cameron IT, Greer IA \& Norman JE 1999 Leukocytes infiltrate the myometrium during human parturition: further evidence that labour is an inflammatory process. Human Reproduction 14 229-236.

Vogel P 2005 The current molecular phylogeny of Eutherian mammals challenges previous interpretations of placental evolution. Placenta $\mathbf{2 6}$ 591-596.

Yang Z, Carter CD, Miller MS \& Bochsler PN 1995 CD14 and tissue factor expression by bacterial lipopolysaccharide-stimulated bovine alveolar macrophages in vitro. Infection and Immunity 63 51-56.

Yang H, Qiu L, Chen G, Ye Z, Lu C \& Lin Q 2008 Proportional change of $\mathrm{CD} 4{ }^{+} \mathrm{CD} 25^{+}$regulatory $\mathrm{T}$ cells in decidua and peripheral blood in unexplained recurrent spontaneous abortion patients. Fertility and Sterility 89 656-661.

Yu Z, Croy BA, Chapeau C \& King GJ 1993 Elevated endometrial natural killer cell activity during early porcine pregnancy is conceptus-mediated. Journal of Reproductive Immunology 24 153-164.

Received 19 May 2008

First decision 11 June 2008

Accepted 17 July 2008 